\title{
PENGARUH WORK FAMILY CONFLICT TERHADAP ORGANIZATIONAL CITIZENSHIP BEHAVIOR DIMEDIASI OLEH KOMITMEN ORGANISASI
}

\author{
Ratya Shafira Arifiani ${ }^{1}$, Viajeng Purnama Putri \\ ${ }^{1}$ Fakultas Ekonomi dan Bisnis, Universitas Muhammadiyah Malang \\ email: ratyashafiraa@umm.ac.id \\ ${ }^{1}$ Fakultas Ekonomi dan Bisnis, Universitas Muhammadiyah Malang \\ email: viajengputri@gmail.com
}

\begin{abstract}
This study discusses conflicts that help workers in dealing with work or family, namely work family conflicts. Work family conflicts are conflicts faced because they cannot balance or harmonize work and family. The impact of work family conflicts varies, from employee performance, OCB to organizational commitment. The object of this research is workers who are married and have fixed working hours. This study aims to see what conflicts have an impact on organizational commitment and $O C B$. This study uses a quantitative approach with explanatory research. Data were collected based on questionnaires distributed to respondents and analyzed using path analysis with the SmartPLS 3 program. The results showed: 1) work family conflict has no effect on OCB; 2) Work family conflict affects organizational commitment; 3) organizational commitment has an effect on $O C B$; and 4) organizational commitment to mediate the effect of family conflict work on OCB.
\end{abstract}

Keywords: Organizational Citizenship Behavior, Organizational Commitment, Work Family Conflict

\begin{abstract}
ABSTRAK
Penelitian ini membahas tentang konflik yang dialami oleh pekerja dalam menghadapi tuntutan pekerjaan maupun keluarga, yaitu work family conflict. Work family conflict merupakan konflik yang dihadapkan karena tidak bisa menyeimbangkan atau menyelaraskan tuntutan pekerjaan dan keluarga. Dampak work family conflict beragam, mulai dari kinerja karyawan, OCB, maupun komitmen organisasi. Objek penelitian ini adalah para pekerja yang sudah berkeluarga dan memiliki jam kerja tetap. Penelitian ini bertujuan untuk mengetahui apakh konflik yang dialami akan berdampak pada komitmen organisasi dan OCB. Penelitian ini menggunakan pendekatan kuantitatif dengan explanatory research. Data dikumpulkan berdasarkan kuesioner yang disebar pada responden dan dianalisis menggunakan path analysis dengan program SmartPLS 3. Hasil penelitian menunjukkan: 1) work family conflict tidak berpengaruh terhadap OCB; 2) work family conflict berpengaruh terhadap komitmen organisasi; 3) komitmen organisasi berpengaruh terhadap OCB; dan 4) komitmen organisasi memediasi pengaruh work family conflict terhadap OCB.
\end{abstract}

Kata kunci: Komitmen Organisasi, Organizational Citizenship Behavior, Work Family Conflict

\section{Pendahuluan}

Seorang karyawan atau anggota organisasi memiliki peranan penting dalam keberlanjutan organisasi. Tuntutan adanya keberlangsungan dan keberhasilan organisasi, maka perlu adanya kerja keras bagi para anggota organisasi. Terlepas dari organisasi, para anggota juga memiliki tanggung jawab di luar organisasi seperti keluarga. Hal ini sering dirasakan oleh pekerja, terutama yang sudah berkeluarga sehingga adanya pertentangan untuk menyelesaikan keduanya secara bersamaan.

Munculnya Work family conflict karena adanya tuntutan tinggi pada pekerjaan yang membutuhkan lebih banyak perhatian namun juga memiliki peranan penting lainnya pada keluarga. Work family conflict terjadi ketika ada ketidak sesuaian antara peran yang satu dengan peran lainnya (inter-role conflict) dengan tekanan yang berbeda antara peran di keluarga atau pekerjaan (Howard, 2008). Pekerja wanita akan lebih sering 
mengalami work family conflict dibandingkan dengan pekerja pria. Di sisi lain wanita memiliki tanggung jawab pada pekerjaannya, tetapi di sisi lain ada tanggung jawab yang lebih besar yaitu terhadap keluarga, telebih yang sudah memiliki anak. Selain itu, fenomena yang terjadi sekarang adalah ketika suami dan istri bekerja (two-worker family) yang memiliki peningkatan pendapatan pada keluarga, namun di sisi lain kurangnya perhatian lebih pada keluarga sehingga lebih beresiko mengalami work family conflict(Nurmayanti, 2019).

Work family conflict merupakan konflik yang terjadi karena adanya tuntutan seseorang dalam memenuhi tuntutan pekerjaan maupun keluarga yang tidak bisa diseimbangkan (Frone et al., 1998). Adaya konflik batin yang terjadi, seringkali pekerja atau karyawan tidak bisa maksimal dalam menjalankan keduanya, sehingga adanya ketimpangan pada hasilnya. Work family conflict terbagi menjadi dua, yaitu work of interfering with family (WIF) dan Family Interfering with work (FIW) (Gutek et al., 1991). Frone et al. (1998) menyatakan pentingnya pengujian dari kedua sisi tersebut, karena hal ini keterhubungan antara satu tipe konflik tidak berarti bahwa jenis konflik yang lain juga harus selalu dihubungkan dengan hal tersebut. Hal ini juga bisa berdampak pada perilaku organisasi lainnya, seperti OCB maupun kinerja karyawan.

OCB (Organizational Citizenship Behaviour) merupakan perilaku sukarela yang dilakukan oleh karyawan di luar tanggung jawab pekerjaannya (Organ \& Philip M, 2006). OCB merupakan salah satu perilaku positif yang dapat dimunculkan oleh karyawan ketika faktor internal maupun eksternal yang mempengaruhi terpenuhi. Perilaku ini muncul pada seorang individu yang melakukan segala sesuatu tanpa adanya paksaan maupun arahan dari pihak lain. OCB bisa muncul karena individu itu sendiri, budaya organisasi, kepuasan kerja, karakteristik pekerjaan, komitemn organisasi (Podsakoff \& MacKenzie, 2000). OCB sendiri terbagi mejadi dua, yaitu OCB-I yaitu perilaku yang memberi manfaat bagi individu dan secara tidak langsung juga memberikan kontribusi pada organisasi sedangkan OCB-O yaitu perilaku-perilaku yang memberikan manfaat bagi organisasi pada umumnya (William \& Anderson, 1991). OCB tidak hanya mempengaruhi organisasi dalam beberapa cara positif, namun dapat juga membawa salah satu konsekuensi negatif yang dialami oleh pekerja Organ \& Philip M, (2006) yang dalam hal ini bisa salah satunya terjadi work family conflict.

Terdapat beberapa penelitian work family conflict dikaitkan dengan OCB. Aurangzeb et al (2017) menemukan adanya pengaruh yang signifikan positif antara work family conflict terhdap OCB, dimana semakin tinggi work family conflict maka semakin tinggi OCB yang dimunculkan oleh karyawan. Berbanding terbalik oleh penelitian Bragger et al. (2005) ; Farida (2014) ; Paat \& Ratnaningsih (2018) yang menyatakan bahwa work family conflict berpengaruh negatif terhadap OCB. Hal ini berarti semakin tinggi konflik yang dialami oleh pekerja maka akan semakin rendah OCB yang dimiliki karyawan. Adanya perbedaan penelitian ini dapat menjadi gap research yang digunakan peneliti dalam mengambil penelitian tentang kedua pengaruh variabel ini.

Selain OCB, work family conflict juga akan memiliki dampak terhadap komitmen organisasi yang dijalankan oleh pekerja. Pekerja yang memiliki konflik diantara pekerjaan maupun keluarga akan lebih mudah menemukan beberpaa halangan dan dapat menurukan komitmen organisasi yang ada pada pekerja (Namasivayam \& Zhao, 2007). Komitmen organisasi merupakan sikap yang mencerminkan sejauh mana seseorang individu mengenal dan terikat pada 
organisasinya (Moorhead \& Griffin, 2013). Komitmen organisasi adalah tingkat di mana seorang pekerja mengidentifikasi suatu organisasi tujuan dan harapan untuk tetap menjadi anggota (Robbins \& Judge, 2015). Pekerja yang memiliki komitmen yang tinggi pada organisasi memiliki peluang yang besar untuk mengembangkan diri dan berpartisipasi dalam proses pengambilan keputusan di organisasi. Steers \& LW, (1991) menguraikan terdapat beberapa faktor yang mempengaruhi komitmen organisasi, diantaranya karakteristik personal, karakteristik kerja, karakteristik organisasi serta sifat dan kualitas pekerjaan. Work family conflict merupakan konflik personal yang didalamnya terdapat konflik yang menyangkut keluarga sehingga memiliki dampak pada komitmen organisasi.

Adanya penelitian Rehman \& Waheed (2012); Buhali \& Margaretha (2013) yang menunjukkan adanya hasil negatif dan signifikan antara work family conflict dengan komitmen organisasional. Sebaliknya, terdapat penelitian Wayne (2013) menyatakan work family conflict memiliki hasil yang positif dan signifikan dengan komitmen organisasi, artinya semakin tinggi konflik yang dimiliki oleh pekerja, maka akan semakin tinggi komitmen organisasi. Selain itu, komitmen organisasi juga memiliki peranan penting dalam meningkatkan OCB.

Komitmen organisasi yang dimiliki oleh pekerja dapat memiliki dampak terhadap peningkatan OCB. Komitmen organisasi merupakan salah satu faktor eksternal dari OCB. Semakin tinggi atau semakin berkomitmen karyawan pada suatu organisasi, maka akan semakin tinggi munculnya perilaku baik seperti OCB. Muhammad (2014); Saher (2012) menemukan adanya komitmen organisasi berpengaruh terhadap OCB. Dari beberapa penelitian yang menyebutkan adanya pengaruh work family conflictterhadap komitmen organisasi dan komitmen organisasi terhadap OCB serta ada gap research maka komitmen organisasi dijadikan sebagai mediasi. Adanya konflik peran yang dialami oleh pekerja tidak akan berpengaruh pada keterlibatan dan keterikatan tinggi pada organisasi, justru akan semakin berpikir ulang jika akan meninggalkan organisasi (Wayne, 2013).Dengan adanya keterlibatan organisasi yang tinggi, maka memunculkan perilaku yang berdampak baik pada organisasi, salah satunya OCB. Objek penelitian ini adalah pekerja yang sudah memiliki keluarga dan yang memiliki jam kerja secara tetap. Penelitian ini dilakukan karena berdasarkan fenomena para pekerja terutama two worker family, dan memiliki anak. Selain itu adanya kesenjangan penelitian antara pengaruh work family conflict terhadap OCB dan menambahkan variabel komitmen organisasi sebagai mediasi sehingga hubungan work family conflict, komitmen organisasi dan dampaknya terhadap OCB penting dilakukan.

\section{Tinjauan Pustaka dan \\ Pengembangan Hipotesis \\ Work-Family Conflict (WFC)}

Work-family conflict (WFC)

merupakan suatu bentuk konflik peran dimana tuntutan peran dari pekerjaan dan keluarga secara mutual tidak dapat disejajarkan dalam beberapa hal (Triaryati, 2003). Adanya pertentangan antara pern pada pekerjaan dan peran di keluarga akan memunculkan sebuah konflik. Pertentangan tersebut bisa ditunjukkan dengan adanya ketidakseimbangan perhatian yang hanya bisa dilihat dari satu sisi dan akan merugikan sisi lainnya. Hal ini terjadi karena adanya tuntutan peran dalam pekerjaan maupun keluarga sehingga karyawan akan berusaha untuk memaksimalkan peran tersebut (Frone et al., 1998). Adapun tuntutan pekerjaan, bisa ditunjukkan dengan adanya deadline 
yang diberikan oleh organisasi untuk diselesaikan tepat waktu, dan tuntutan untuk keluarga bisa ditunjukkan dengan menangani tugas rumah tangga atau menjaga anak. Tuntutan dari keluarga bisa dilihat dari jumlah anggota keluarga yang memliki ketergantungan dengan anggota yang lain (Yang, 2000).

Work-family conflict memiliki dua sisi yang perlu diperhatikan, yaitu Workfamily conflict dan Family-Work conflict. Work-family conflict memiliki tiga jenis yaitu sebagai berikut (Greenhaus \& Beutell, 1985): Time-based conflict. Waktu yang dibutuhkan untuk menjalankan salah satu tuntutan (keluarga atau pekerjaan) dapat mengurangi waktu untuk menjalankan tuntutan yang lainnya (pekerjaan atau keluarga); Strain-based conflict. Terjadi saat tekanan dari salah satu peran mempengaruhi kinerja peran lainnya; Behavior-based conflict. Berhubungan dengan ketidaksesuaian antara pola perilaku dengan yang diinginkan oleh kedua bagian (pekerjaan atau keluarga).

Work-family conflict dapat disimpulkan sebagai salah satu konflik yang diiliki karyawan secara intrapersonal dimana memiliki dua tekanan peran dan tidak dapat disejajarkan secara bersamaan. Selain Work-family conflict, terdapat sisi lain yang perlu diperhatikan yaitu Konflik keluarga-pekerjaan atau family-work conflict (FWC). family-work conflict merupakan sebuah bentuk dari konflik antar peran dimana tekanan dari peran dalam pekerjaan dan keluarga saling bertentangan, yaitu menjalankan peran dalam pekerjaan menjadi lebih sulit karena juga menjalankan peran dalam keluarga, begitu juga sebaliknya, menjalankan peran dalam keluarga menjadi lebih sulit karena juga menjalankan peran dalam pekerjaan (Greenhaus \& Beutell, 1985). Jenis konflik ini akan lebih sering dialami oleh pekerja wanita. Pekerja wanita akan memiliki tuntutan yang lebih besar dibanding dengan pria, karena keluarga juga menjadi prioritas utama yang wajib untuk dilakukan. Dampak dari Familywork conflict (FWC) adalah menimbulkan stres kerja pada pekerja (Failasuffudien, 2003). Konflik ini menekankan bahwa keluarga dapat mengganggu pekerjaan, artinya sebagian besar waktu dan perhatian digunakan untuk menyelesaikan urusan keluarga sehingga mengganggu pekerjaan dan bisa menjadi beban sehingga tidak dapat bekerja secara maksimal (Murtiningrum, 2005).

\section{Organizational Citizenship Behaviour (OCB)}

Organizational

Citizenship

Behavior (OCB) yaitu individu secara sukarela membantu orang lain di pekerjaan tanpa mengharapkan adanya imbalan (Bies \& Organ, 1989). Organ \& Philip M (2006) memaparkan OCB merupakan perilaku individu yang terdiskresi, secara tidak langsung atau eksplisit diakui dengan sistem reward dan agregat untuk meningkatkan fungsi efektif dan efisien sebuah organisasi. William \& Anderson (1991) membagi OCB dalam dua kategori, yaitu OCB-O dan OCB I. OCB-O atau Organizational Citizenship Behavior-Organizations adalah perilakuperilaku yang memberikan manfaat bagi organisasi pada umumnya. OCB-I atau Organizational Citizenship BehaviorIndividuals adalah perilaku-perilaku yang memberikan manfaat bagi individu dan secara tidak langsung juga memberikan kontribusi pada organisasi.

Terdapat lima kategori utama dalam OCB (Organ \& Philip M, 2006): Altruism atau perilaku suka menolong. Sikap ini ditunjukkan dengan menolong orang lain yang dalam hal ini adalah rekan kerja tanpa adanya paksaan; Conscientiousness, yaitu Perilaku yang ditunjukkan karyawan dengan memenuhi persyaratan yang diajukan oleh organisasi seperti mematuhi peraturan dan tidak melanggar peraturan. Civic virtue yaitu 
perilaku yang mengutamakan kepentingan organisasi dibandingkan dengan kepentingan individu; Sportmanship. Sikap ini juga bisa ditunjukkan dengan tanggung jawab terhadap apa yang telah dilakukan dan menanggung segala risiko yang dihadapi; Courtesy yaitu Perilaku yang ditujukan untuk mencegah masalah yang berkaitan dengan pekerjaan yang terjadi dengan orang lain.

Organ \& Philip M (2006) mengatakan OCB dipengaruhi oleh dua faktor, yaitu faktor internal dan ekternal. Faktor internal adalah dari diri sendiri seperti kepuasan kerja, kepribadian, dan komitmen. Salah satu faktor yang menyebabkan adanya OCB adalah seseorang puas terhadap pekerjaannya. Semakin karyawan merasa puas dan senang terhadap pekerjaannya, maka akan semakin ekstra dalam melakukan tugasnya, sehingga menimbulkan sikapsikap positif yang berdampak baik bagi organisasi. Faktor yang berasal dari luar karyawan (eksternal) adalah kepemimpinan dan budaya organisasi. Menurut Organ dalam Organ \& Philip M (2006) Budaya organisasi merupakan suatu kondisi awal munculnya sikap OCB. Semakin budaya organisasi kuat, maka akan menimbulkan nilai-nilai positif, dan akan berdampak pada perilaku-perilaku positif lainnya.

\section{Komitmen Organisasi}

Keberlanjutan organisasi dipengaruhi juga dengan adanya komitmen organisasi dari para pekerja. Semakin tinggi komitmen yang dianut oleh pekerja, maka akan terdorong untuk bertanggungjawab lebih pada tugasnya. Keterlibatan pekerjaan yang tinggi berarti memihak pada pekerjaan tertentu seseorang individu. Komitmen organisasional yang tinggi berarti memihak organisasi yang merekrut individu tersebut (Robbins \& Judge, 2015). Komitmen organisasi adalah sikap seseorang mengenal dan terikat pada organisasi (Moorhead \& Griffin, 2013).
Komitmen organisasi berkaitan dengan loyalitas karyawan sehingga keberlanjutan dan keberhasilan organisasi menjadi tujuan utama bagi karyawan. Allen dan Mayer dalam Greennberg \& Baron (2000) menyatakan terdapat tiga dimensi komitmen organisasi, yaitu: Affective commitment yaitu adanya keterikatan emosional dan keterlibatan pada organisasi. Komitmen ini memunculkan keinginan yang kuat dari karyawan untuk bekerja pada organisasi; continuance commitment yaitu komitmen yang berkelanjutan, sehingga mempertimbangkan kerugian yang didapat ketika keluar dari organisasi; normative commitment yaitu keinginan untuk tetap berada pada organisasi.

\section{Pengaruh work family conflict terhadap OCB}

Work family conflict dapat terjadi pada pekerjaa ketika memiliki tuntutan pekerjaan dan keluarga, yang biasanya dialami oleh pekerja wanita. Penelitian yang dilakukan oleh Aurangzeb (2017) menyatakan pengaruh yang signifikan positif antara work family conflict terhdap OCB. Semakin tinggi konflik yang dialami maka tidak akan berdampak pada pekerja untuk melakukan OCB di organisasi. (Bragger et al., 2005; Farida, 2014; Paat \& Ratnaningsih, 2018) menemukan bahwa work family conflict memiliki pengaruh signifikan negatif terhadap OCB.

\section{Hipotesis 1. Work family conflict berpengaruh signifikan terhadap OCB}

\section{Pengaruh work family conflict terhadap komitmen organisasi}

Konflik yang dialami oleh pekerja yaitu work family conflict akan memiliki dampak pada keterlibatan dan partisipasi karyawan pada pekerjaannya, sehingga akan berdampak pula pada komitmen organisasi yang dimiliki oleh pekerja. Buhali \& Margaretha (2013) menemukan adanya hubungan negatif antara work 
family conflict dengan komitmen organisasi. Balmforth \& Gardner (2006) juga menunjukkan bahwa work family conflict memiliki hubungan negatif dengan OCB. Hubungan negatif ini terjadi karena adanya kesulitan dalam menyeimbangkan perannya dalam pekerjaan maupun peran pada keluarga sehingga akan susah untuk berkomitmen kepada organisasi.

\section{Hipotesis 2. Work family conflict berpengaruh signifikan terhadap komitmen organisasi}

\section{Pengaruh Komitmen Organisasional terhadap OCB}

Komitmen organisasi merupakan keterikatan pekerja dan keterlibatan pada organisasi dan bertanggung jawab untuk mencapai tujuan yang diinginkan oleh pekerja itu sendiri dan organisasi sehingga memiliki keinginan untuk tetap tinggal di organisasi tersebut (Greennberg \& Baron, 2000). Komitmen organisasi memiliki peranan penting baik kinerja maupun perilaku baik lainnya pada organisasi, salah satunya OCB. Penelitian Maharani et al. (2017); Muhammad (2014) menyatakan adanya pengaruh signifikan antara komitmen organisasi terhadap OCB. Semakin kuat komitmen organisasi yang dimiliki pekerja, maka akan semakin tinggi peluang munculnya OCB.

\section{Hipotesis 3. Komitmen organisasi berpengaruh signifikan terhadap OCB}

\section{Komitmen organisasi memediasi pengaruh work family conflict terhadap OCB}

Keterlibatan pekerja memiliki peranan penting bagi organisasi. Hal ini ditunjukkan dengan adanya komitmen organisasi dan perilaku baik lainnya. Adanya konflik yang dialami oleh pekerja yaitu work family conflict akan berpengaruh pula pada organisasi, baik dari segi perilaku maupun kinerja. Semakin tinggi konflik yang dialami diharapkan komitmen organisasi juga tinggi, dan berdampak pada perilaku organisasi yang baik seperti OCB. Wayne (2013) menemukan adanya pengaruh signifikan positif antara work family conflict terhadap OCB. Komitmen organisasi merupakan keterikatan pekerja dan keterlibatan pada organisasi dan bertanggung jawab untuk mencapai tujuan yang diinginkan oleh pekerja itu sendiri dan organisasi sehingga memiliki keinginan untuk tetap tinggal di organisasi tersebut (Greennberg \& Baron, 2000). Komitmen organisasi memiliki peranan penting baik kinerja maupun perilaku baik lainnya pada organisasi, salah satunya OCB. Penelitian Maharani et al. (2017); Muhammad (2014) menyatakan adanya pengaruh signifikan antara komitmen organisasi terhadap OCB. Semakin kuat komitmen organisasi yang dimiliki pekerja, maka akan semakin tinggi peluang munculnya OCB.

Hipotesis 4. Komitmen organisasi memediasi pengaruh work family conflict terhadap OCB

\section{Metode Penelitian}

Penelitian ini menggunakan pendekatan kuantitatif. Pendekatan kuantitatif berfokus pada penggunaan angka mulai dari pengumpulan data, penafsiran terhadap data tersebut, serta penampilan dari hasilnya adalah data dalam bentuk angka atau data kualitatif yang diangkakan (Sugiyono, 2013). Sedangkan jenis penelitian ini adalah explanatory research, yang memiliki tujuan untuk menguji hipotesis yang sudah ditentukan. Penelitian ini menganalisis dan menguji pengaruh work family conflict, komitmen organisasi, dan OCB.

Penelitian ini memilih pekerja atau karyawan yang sudah berkeluarga sebagai obyek penelitian, terutama yang memiliki jam kantor yang sudah ditetapkan dan teratur. Alasan penentuan obyek penelitian tersebut adalah untuk membandingkan repon dari pekerja pria 
maupun wanita yang memiliki jam kerja tertentu dan bagaimana cata menghadapi konflik pada pekerjaan maupun keluarga. Lokasi penelitian diadakan di Indonesia, karena jumlah two worker family sangat besar. Populasi merupakan subyek yang memiliki karakteristik tertentu dan memiliki kesempatan untuk dijadikan sebagai sampel penelitian (Umar, 2004). Populasi dalam penelitian ini adalah seluruh pekerja pria dan wanita yang memiliki jam kerja yang sudah ditentukan dan sudah berkeluarga.

Sampel dari penelitian ini adalah sejumlah pekerja pria dan wanita yang sudah berkeluarga dan memiliki jam kerja tertentu. Menurut Hair et al. (2015)penentuan jumlah sampel maksimal 300 ketika memiliki konstruk konstruk $\leq 7$, tingkat communality minimal 0,45 dan indikator atau item tidak valid kurang dari tiga pada setiap konstruk. Sehingga penelitian ini diasumsikan maksimal 300 sampel tujuannya untuk memberikan data yang akurat, untuk hasil penelitian dapat semakin mendekati realita. Ukuran sampel pada penelitian ini didasarkan pada jumlah sampel minimal dengan melihat banyaknya jumlah variabel yang diuji (Cooper dan Schindler, 2014). Penetapan jumlah sampel minimal dengan variabel $\leq 5$ maka jumlah sampelnya adalah 100 . Metode pengambilan sampel penelitian adalah non-probability sampling dimana tidak diketahui secara jelas jumlah populasi. Metode yang digunakan dari non-probability sampling adalah judgemental sampling dimana sampling ditentukan dengan adanya kriteria tertentu untuk memperoleh informasi yang lebih akurat. Kriteria sample yang digunakan dalam memilih responden adalah sebagai berikut:

a. Pekerja pria dan wanita yang sudah berkeluarga dan memiliki anak

b. Pekerja pria dan wanita yang memiliki jam kerja yang sudah ditentukan

\section{Hasil dan Pembahasan}

Pada penelitian ini menggunakan metode kuantitatif dengan menyebarkan kuesioner kepada 100 responden. Karakteristik responden berdasarkan jenis kelamin, didominasi oleh pria sejumlah $64 \%$ dan wanita sejumlah 36\%. Ini menunjukkan bahwa lebih banyak responden berjenis kelamin pria daripada responden berjenis kelamin wanita. Hal ini disebabkan karena pria lebih banyak berperan sebagai kepala keluarga yang bertugas mencari nafkah untuk memenuhi kebutuhan anggota keluarganya. Karakteristik responden untuk usia, sebagian besar responden berusia 20-25 Tahun sejumlah 68\% dan usia 26-30 Tahun sebesar 32\%. Hal ini menunjukkan bahwa responden sebagian besar pada rentang usia produktif sehingga responden masih memiliki semangat dan baik secara fisik yang berdampak pada kinerja.

Karakteristik responden jenjang pendidikan terakhir menunjukkan bahwa responden dengan tingkat pendidikan SMA/SMK mendominasi dengan jumlah $88 \%$, dan responden dengan jenjang pendidikan diploma/sarjana sejumlah 12\%. Hal ini mengindikasikan bahwa semakin tinggi tingkat pendidikan seseorang, semakin banyak pengetahuan yang didapat dan dapat meminimalisir atau dewasa dalam menanggapi sebuah masalah ditinjau dari segi pengalaman dalam bekerja dengan tingkat pendidikan yang lebih tinggi. Responden berdasarkan masa kerja dijelaskan bahwa sebagian besar responden dalam penelitian ini mempunyai masa kerja selama 1-5 Tahun yaitu sebesar 44\%. Selanjutnya untuk masa kerja selama 6-10 tahun sejumlah 56 $\%$. Masa kerja yang lebih lama erat kaitannya dengan pengalaman dan pemahaman mengenai job description yang lebih baik. Pengalaman dan pemahaman ini akan membantu dalam mengatasi masalah yang timbul, baik dilingkungan kerja maupun keluarga. 
Hasil dari analisis data menjelaskan pengaruh antara work family conflict dan Organizational Citizenship Behavior baik secara langsung maupun tidak langsung ditunjukkan pada gambar 1 berikut:

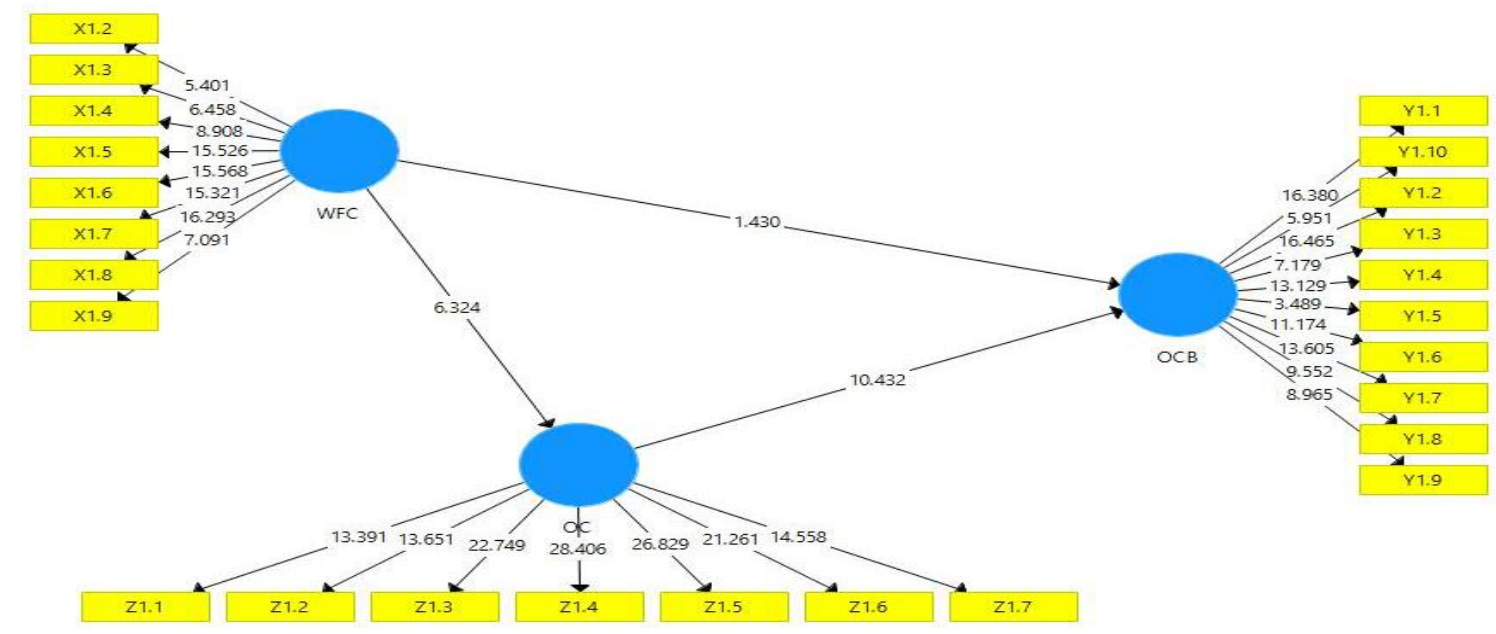

\section{Gambar 1. Hasil Analisis Data}

Berikut hasil uji statistik pengaruh langsung disajikan pada tabel 1 berikut:

Tabel 1. Hasil Analisis Pengaruh Langsung

\begin{tabular}{cccccc}
\hline $\mathbf{H}$ & Variabel Bebas & $\begin{array}{c}\text { Variabel } \\
\text { Terikat }\end{array}$ & t Statistik & p-value & Ket. \\
\hline 1 & $\begin{array}{c}\text { Work family } \\
\text { conlfict }\end{array}$ & OCB & 1.430 & 0.153 & $\begin{array}{c}\text { Tidak } \\
\text { Signifikan }\end{array}$ \\
\hline 2 & $\begin{array}{c}\text { Work family } \\
\text { conflict }\end{array}$ & $\begin{array}{c}\text { Komitmen } \\
\text { organisasi }\end{array}$ & 6.324 & 0.000 & Signifikan \\
\hline 3 & $\begin{array}{c}\text { Komitmen } \\
\text { organisasi }\end{array}$ & OCB & 10.432 & 0.000 & Signifikan \\
\hline
\end{tabular}

\section{Sumber: Data Primer diolah, 2020}

Hasil pengujian pengaruh langsung antara work family conflict terhadap OCB diperoleh nilai t-statistik 1.430 dan $p$-value 0.153 . karena nilai t-statistik $1.430<1.96$ dan $\mathrm{p}$-value $0.153>0.05$ maka work family conflict tidak berpengaruh signifikan terhadap OCB sehingga $\mathrm{H} 1$ yang menyatakan bahwa work family conflict berpengaruh signifikan terhadap OCB ditolak. Hasil pengujian pada hipotesis 2 yaitu pengaruh work family conflict terhadap komitmen organisasi diperoleh nilai t-statistik >1.96 yaitu 6.324 dengan p-value 0.000 sehingga work family conflict berpengaruh signifikan terhadap komitmen organisasi dan $\mathrm{H} 2$ diterima. Hasil pengujian langsung berikutnya adalah pengaruh komitmen organisasi terhadap OCB. Hasil menunjukkan t-statistik 10.432>1.96 dan p-value $0.000<0.05$ maka komitmen organisasi berpengaruh signifikan terhadap OCB sehingga $\mathrm{H} 3$ diterima.

\section{Tabel 2. Hasil Analisis Pengaruh Tidak Langsung}

\begin{tabular}{cccccccc}
\hline $\mathbf{H}$ & $\mathbf{A}$ & $\mathbf{B}$ & $\mathbf{S E}_{\mathbf{A}}$ & $\mathbf{S E}_{\mathbf{B}}$ & t-stat. & Sign. & Ket \\
\hline H4 & 0.477 & 0.679 & 0.075 & 0.065 & 5.432 & 0.000 & Signifikan
\end{tabular}

Sumber: Data Primer diolah, 2020 
Komitmen organisasi memediasi work family conflict terhadap OCB. Hasil analisis diperoleh nilai 5.432> 1,96 dan signifikan $0,000<0,05$. Hasil analisis mengungkapkan bahwa pengaruh variabel work family conflict terhadap komitmen organisasi dan komitmen organisasi terhadap OCB memiliki hasil yang signifikan sedangkan pengaruh langsung work family conflict terhadap OCB tidak signifikan. Sehingga, variabel komitmen organisasi dalam penelitian ini adalah variabel mediasi sempurna (mediasi lengkap). Dengan demikian, Hipotesis 4 diterima.

Hasil penelitian menunjukkan bahwa work family conflict tidak berpengaruh signifikan terhadap OCB. Work family conflict merupakan konflik yang terjadi karena adanya tuntutan peran ganda yaitu tuntutan pekerjaan dan keluarga. Semakin tinggi work family conflict yang terjadi pada seorang pekerja, maka tidak akan berdampak pada OCB yang dimiliki. Tingginya work family conflict akan memberikan tekanan yang tinggi pada pegawai baik dari pekerjaan maupun keluarga. Namun OCB sendiri muncul dengan adanya factor-faktor seperti dari individu itu sendiri, komitmen organisasi, pemimpin, dan lain sebagainya. Adanya konflik akan jarang memunculkan perilaku yang berdampak baik bagi organisasi, seperti OCB.

Hasil penelitian juga menunjukkan adanya pengaruh signifikan antara work family conflict terhadap komitmen organisasi. Adanya konfik pada pekerjaan maupun keluarga tidak mempengaruhi penurunan komitmen individu pada organisasi, bahkan tetap berkomitmen pada organisasi. Adanya tuntutan pekerjaan dan tanggung jawab karyawan pada organisasi membuat seseorang akan lebih bertanggung jawab terhadap pekerjaannya. Selain itu, adanya kewajiban kepada keluarga dengan menafkahi atau mencukupi kebutuhan sehari-hari juga menjadi tuntutan utama bagi para pekerja yang memiliki keluarga, sehingga komitmen organisasi juga semakin kuat. Penelitian ini sejalan dengan penelitian yang dilakukan oleh (Buhali \& Margaretha, 2013); Balmforth \& Gardner (2006) bahwa adanya pengaruh signifikan antara work family conflict terhadap komitmen organisasi.
Komitmen organisasi merupakan salah satu bentuk keterikatan dan keterlibatan para pekerja dengan organisasinya. Adanya keterlibatan tersebut, akan menimbulkan perilaku-perilaku positif yang berdampak baik bagi organisasi, salah satunya OCB. Hasil penelitian menunjukkan adanya pengaruh signfikan antara komitmen organisasi terhadap OCB. Semakin kuat dan terikatnya seseorang dalam organisasi, maka akan semakin meningkatkan perilaku OCB. OCB merupakan perilaku sukarela yang dilakukan oleh seseorang di luar tanggung jawab tugasnya yang juga akan memiliki dampak baik bagi efektivitas dan tujuan organisasi. Maharani et al. (2017) juga menemukan adanya pengaruh signifikan antara komitmen organisasi terhadap OCB.

Hasil penelitian menunjukkan komitmen organisasi sebagai peran mediasi antara work family conflict terhadap OCB. Adanya pengaruh yang tidak signifikan antara work family conflict terhadap OCB namun adanya pengaruh antara work family conflict terhadap komitmen organisasi dan komitmen organisasi terhadap OCB sehingga komitmen organisasi memiliki peran menjadi perantara. Adanya tuntutan antara pekerjaan dan keluarga tidak menurunkan nilai komitmen para pekerja bagi organisasi, seperti halnya pada indikator komitmen organisasi yaitu yaitu continuance commitment atau komitmen berkelanjutan, dimana pekerja akan memilih untuk bertahan di organisasi karena kekhawatiran jika meninggalkan organisasi akan berdampak pada organisasi dan keluarga. Dengan adanya komitmen organisasi yang tinggi pula maka akan memunculkan perilaku yag baik organisasi, sehingga munculnya OCB juga semakin tinggi.

\section{Kesimpulan}

Kesimpulan pada penelitian ini adalah sebagai berikut: Work family conflict tidak berpengaruh terhadap OCB. Faktor yang memunculkan OCB tidak didasari oleh adanya work family conflict melainkan dari individu itu sendiri atau factor lainnya. Work family conflict berpengaruh terhadap komitmen organisasi. Adanya tuntutan dari 
pekerjaan maupun keluarga akan meningkatkan komitmen pekerja pada organisasi, karena adanya beberapa factor yang mendukung pekerja untuk tetap bertahan pada organisasi. Komitmen organisasi berpengaruh terhadap OCB, dimana adanya keterlibatan dan keterikatan pada organisasi akan memunculkan perilaku baik dalam organisasi yang berdampak pada efektivitas organisasi, salah satunya adalah OCB. Komitmen organisasi memiliki peran mediasi antara pengaruh work family conflict terhadap OCB.

\section{DAFTAR PUSTAKA}

Aurangzeb. (2017). Work family conflict and Organizational Citizenship Behavior in Bank Employees. Industrial Engineering Letters, 7(2).

Balmforth, K., \& Gardner, D. (2006). Conflict and Facilitation between Work and Family: Realizing the Outcomes for Organizations. New Zealand Journal of Psychology, 35(2).

Bies, R. J., \& Organ, D. W. (1989). Organizational Citizenship Behavior: The Good Soldier Syndrome. The Academy of Management Review, 14(2), 294. https://doi.org/10.2307/258426

Bragger, J. D., Rodriguez-Srednicki, O., Kutcher, E. J., Indovino, L., \& Rosner, E. (2005). Work-family conflict, workfamily culture, and organizational citizenship behavior among teachers. Journal of Business and Psychology, 20(2), 303-324.

Buhali, G. A., \& Margaretha, M. (2013). Pengaruh work-family conflict terhadap komitmen organisasi: kepuasan kerja sebagai variabel mediasi. Jurnal Manajemen, 13(1).

Failasuffudien, A. (2003). Hambatan Karir Wanita. EKOBIS, 4(2), 241-248.

Farida, N. (2014). Pengaruh work family conflict terhadap Organizational Citizenship Behavior pada PT. Tanjung Unggul Mandiri. E-Journal.

Frone, M. R., Rusell, M., \& Cooper, M. L. (1998). Antecedents and Outcomes of
Work family conflict: Testing a Model of The Work-Family Interface. Journal of Applied Psychology.

Greenhaus, J. H., \& Beutell, N. J. (1985). Sources of Conflict Between Work and Family Roles. Academy of Management Review, 10(1), 76-88.

Greennberg, \& Baron. (2000). Budaya dan Komiten Organisasi. Erlangga.

Gutek, B. A., Searle, S., \& Klepa, L. (1991). Rational Versus Gender Role Explanations for Work-Family Conflict. Journal of Applied Psychology, 76(4), 560-568. https://doi.org/10.1037/00219010.76.4.560

Howard, J. . (2008). Balancing Conflicts Of Interest When Employing Spouses. Employee Responsibiity Rights Journal, 20, 29-43.

Maharani, V., Surachman, Sumiati, \& Sudiro, A. (2017). The Effect of Transformational Leadership on Organizational Citizenship Behavior Mediated by Job Satisfaction and Organizational Commitment. International Journal of Economic Research, 14(3).

Moorhead, G., \& Griffin, R. . (2013). Perilaku Organisasi. Salemba Empat.

Muhammad, A. (2014). Perceived Organizational Support and Organizational Citizenship Behavior: The Case of Kuwait. International Journal of Business Administration, 5(3).

Murtiningrum, A. (2005). Analisis Pengaruh Konflik Pekerjaan Keluarga Terhadap Stress Kerja Dengan Dukungan Sosial Sebagai Variable Moderasi (Studi Kasus Pada Guru Kelas 3 Smp Negeri Di Icabupaten Kendal). Universitas Diponegoro.

Namasivayam, K., \& Zhao, X. (2007). An investigation of the moderating effects of organizational commitment on the relationships between work-family conflict and job satisfaction among hospitality employees in India. Tourism Management, 28(5), 1212-1223. https://doi.org/10.1016/j.tourman.2006.0 9.021

Nurmayanti, C. Z. H. S. (2019). Influence of Work-Family Conflict Onorganizational 
Commitment and Organizational Citizenship Behavior (Study at the Manpower and Transmigration Department of West Nusa Tenggara Province). International Journal of Science and Research (IJSR), 8(2), 705712.

https://www.ijsr.net/archive/v8i2/ART20 194556.pdf

Organ, D. W., \& Philip M, P. (2006). Organizational Citizenship Behavior: Its Nature, Antecendent, And Consequense. Sage Publications, Inc.

Paat, F., \& Ratnaningsih, I. (2018). Hubungan antara Konflik Pekerjaan-Keluarga dengan Perilaku Kewargaan Organisasi pada Guru Wanita Sekolah Menengah Kejuruan Negeri di Kecamatan Semarang Timur Kota Semarang. Jurnal Empati, 7(1), 238-246.

Podsakoff, P., \& MacKenzie. (2000). Organizational Citizenship Behaviors: A Critical Review of the Theoretical and Empirical Literature and Suggestions for Future Research. Journal of Management, 26(3), 513-563.

Rehman, R. R., \& Waheed, A. (2012). WorkFamily Conflict and Organizational Commitment: Study of Faculty Members in Pakistani Universities. Pakistan Journal of Social and Clinical Psychology, 10(1), 23-26.

Robbins, S. P., \& Judge, T. A. (2015). Perilaku Organisasi edisi 16. Salemba Empat.

Saher, K. (2012). Role of Commitment in the Development of Employee's Citizenship Behaviour: Evidence from banking Sector of Pakistan. International Journal of Business and Social Science, 3(20), 247-254.

Steers, R., \& LW, P. (1991). Motivation and work behavior. McGraw-Hill.

Triaryati, N. (2003). Pengaruh Adaptasi Kebijakan Mengenai Work Family Issue terhadap Absen dan Turnover. Jurnal Manajemen Dan Kewirausahawan, 5(1), 85-96.

Wayne, J. H. (2013). Family-Supportive Organization Perceptions and Organizational Commitment: The Mediating Role of Work-Family
Conflict and Enrichment and Partner Attitudes,. Journal of Applied Psychology, 98(4), 606-622.

William, L., \& Anderson, S. (1991). Job Satisfaction and Organizational Commitment as Predictors of Organizational Citizenship and In-Role Behaviors. Journal of Management, 17(3), 601-607.

Yang. (2000). Sources of Work - Family Conflict: A Sino - US Comparison the Effect of Work and Family Demands. Academy of Management Journal, 43(99), 1-18. 